\title{
The Media and Information Literacy Program of the Ateneo de Manila Grade School
}

\author{
Maria Victoria E. Dela Cruz \\ Ateneo de Manila Grade School \\ Katipunan Avenue, Loyola Heights, Quezon City 1108 \\ Philippines \\ vdelacruz@ateneo.edu
}

\begin{abstract}
The study was conducted to measure the effectiveness of the Media Instruction Program (MIP) of the Ateneo de Manila Grade School through the MIP Modules taught to selected Grade Five students enrolled for SY 2015-2016. Students were given a pre-test at the beginning of SY 2015-2016 to measure their information literacy skills. After attending MIP sessions at the Katigbak Educational Media Center (KEMC), they were given post-test to measure the difference in their pre-test and post-test scores. There was an observed increase and significant improvement in the test scores of Grade Five students after they have been exposed to Media Instruction Program.
\end{abstract}

Keywords: information literacy, learning outcomes, media and information literacy program 


\section{Background of the Study}

A library or media center serves its clientele by giving varied programs and services suited to their needs. Through the programs that libraries provide, the clientele are kept abreast of new trends in learning and are exposed to different learning opportunities. To make the patrons independent users of information it is important to give them an appropriate library media program or library instruction program that will help them become better individuals.

The existence of a library instruction in an institution has to be clearly defined by the library's mission and vision. The students, as a very important group of stakeholders in an educational institution have to be aware of the relevance of the library instruction in relation to the curriculum. The practice of going to the library or media center to maximize the use of its resources, programs, and services is a habit that has to be so instilled among the students for lifelong learning. This can be done through library instruction either as an independent program of the library or in partnership with the curriculum.

The role of librarians as educators has become very influential in providing library instruction. With the current situation, where most students in Basic Education schools belong to the $Z$ generation, students are described as internet savvy kids and possess high sophisticated media skills. School librarians are faced with a bigger challenge of providing quality and meaningful library instruction. Librarians have to be trained to make use of teaching strategies that would enjoin students to learn the basic skills in seeking, understanding, 
evaluating, communicating, and using information effectively. But how will school librarians measure the knowledge gained by the students from library instruction? Studies related to information literacy show that it is the outcomes of the program that indicate the effects of a library instruction. It is therefore relevant to study the impact of the program based on the students' acquired information literacy (IL) skills.

In the Ateneo de Manila Grade School (AGS), a library instruction program known as the Media Instruction Program (MIP) is provided by the Katigbak Education Media Center (KEMC). This is handled and facilitated by the AGS librarians. Established in 1980's, it started as a reading period for the students to borrow and read books in the library. It aimed to promote love for reading, making the students aware of the library resources. Library sessions were semi-structured and only basic library skills were taught. Borrowing was an important part of the lesson. Discussions with the supervisors namely the Grade Level Coordinators (GLCs), the Reading Subject Area Coordinator (SAC) and the Instructional Media Center (IMC) coordinator were mainly on how to make the students readers.

In the 1990's, Media Instruction Program became more formal. The need to make students media oriented was addressed by including media education topics in MIP. The English subject became the bigger umbrella of MIP. Topics taught in English and MIP were streamlined to continuously improve the program. Furthermore, the MIP needed to adopt important topics and skills to ensure that students are not left behind. Students were taught the proper ways of using library resources.

\section{The Katigbak Educational Media Center (KEMC)}

The Katigbak Educational Media Center of the Ateneo de Manila Grade School promotes and develops independent and lifelong learners that are critical thinkers, globally competitive, socially aware, service oriented, and spiritually grounded (AGS KEMC, 2008, p.1).

The KEMC started as a traditional library when the Ateneo Grade School was transferred from Intramuros to Loyola Heights in 1954. In 1957, the Audiovisual section, under the leadership of Fr. Luis Candelaria, then Headmaster, was created to address the growing needs of students and teachers.

In 1971, Fr. Rodolfo Malasmas, S.J., then Headmaster initiated the integration of the Library and the Audiovisual section to form the Instructional Media Center. This move aimed to provide students and teachers with multi-media resources to enhance teaching and learning 
opportunities. In 1977, the Instructional Media Center was renamed to Educational Media Center. In July 1984, Fr. Asterio J. Katigbak, S.J., then Headmaster, shared an invaluable contribution to the construction of the new EMC building. It was for this reason, that in school year 2008-2009, the school named the EMC as the KEMC. The school pays tribute to his effort in this noticeable endeavor.

Today, the Katigbak Educational Media Center (KEMC) of the Ateneo de Manila Grade School contains diverse collection of print and multi-media resources. It supports the academic program of the school by providing materials and services important to the students' education and formation. It responds to various needs of school stakeholders by acquiring and organizing print and non-print materials for classroom instruction. It makes materials available for personal and professional growth of each individual. The KEMC ensures that its resources are maximized to answer the school community's educational needs. Through the collaborative effort of school personnel, the KEMC provides several programs and services appropriate for students of different levels and for teachers of different subject areas (AGS KEMC, 2008).

The Katigbak Educational Media Center Manual of Information 2008 states that: The Media Instruction Program aims to teach students to be skillful and discriminating users of print and non-print media. It is designed to develop the habit of inquiry and stimulate the growth and development of the young mind in independent learning. It also aims to develop appreciation for literacy in the different forms of media (AGS KEMC, 2008, p.4).

Media Instruction Program modules were made by the researcher using the ASSURE (Gagne, Briggs, and Wagner, 1992) model. The ASSURE model is a modified process of Instruction Systems Design that involves steps in planning an effective instruction - Analyze learners, State objectives, Select instructional methods, media and materials, Utilize instructional methods, media and materials, Require learner participation, and Evaluate and revise (Gagne, Briggs, \& Wagner, 1992). Learners' characteristics and abilities are of great importance in developing an instruction. These would gauge how the instructional objectives are formulated as the teacher would know what to expect from the learners. As educators, it is necessary to determine where the learners are at before coming up with any instructional design. Recognizing the individual's interests and needs would be able to direct the teacher to find appropriate instructional materials suited to the capabilities of learners. Being familiar with the learners' uniqueness, the use of selected instructional materials can easily be done to facilitate the teaching and learning process. In this phase, learners' participation is necessary to be manifested in the development of the lesson. Teachers serve as a guide to 
direct learners to be involved in the activities of the lesson. Student-centered activities are highly recommended to require learners' active participation. Having completed these steps, it would be good to take some time to look into the strengths and weaknesses of the accomplished tasks. It is in this phase that evaluation is done to continue the good points and revise areas to improve on. The ASSURE model process comprises the steps taken by the researcher in preparing the modules except for the last phase that is evaluation, which would entail more time of revising the modules after these are administered.

\section{Statement of the Research Problem}

Towards improving the Media Instruction Program (MIP) of the Ateneo de Manila Grade School, the researcher aimed to look into the effects of teaching MIP on students' information literacy (IL) skills.

The study sought to answer the following research questions:

1. What are the pre-test information literacy skills of Grades Five students?

2. What are the post-test information literacy skills of Grades Five students?

3. Is there a difference in the pre-test and post-test information literacy (IL) skills of the Grade Five students after they have been exposed to Media Instruction Program (MIP)?

\section{Research Objectives}

The study aims to determine the effects of the MIP modules on the information literacy skills of Grade Five students.

The objectives of the study are the following:

1. To develop a set of modules for Grade Five Media Instruction Program;

2. To determine the pre-test information literacy skills of Grade Five students;

3. To determine the post-test information literacy skills of Grade Five students;

4. To determine the difference in the pre-test and post-test information literacy skills of Grade Five students after they have been exposed to Media Instruction Program.

\section{Review of Related Literature}

Educators play a pivotal role in ensuring that the curriculum is aligned with other components of the school. Curriculum planning involves a systematic process of discussing topics and skills to be taught as well as delivery of instruction. "As curriculum is central to the educational process, so too, is the library media program central to curriculum" (Eisenberg \& Berkowitz, 1988, p.3). Library media programs aim to teach library and information skills essential to perform problem-solving process efficiently. When students are able to acquire these skills, they learn the systematic way of information-problem solving (Eisenberg \& Berkowitz, 1988). In the study conducted by Sakr (2009), she determined that 
the effectiveness of information literacy program and the key role of school library were considered influential in the development of students' information literacy skills. The study was done by getting the perceptions of all students and teachers of second and fourth grades, 18 parents, and 2 librarians on the information literacy program offered by a private school in Lebanon. The study showed the good influence of librarians in encouraging students to read more through teaching and learning interactions. Observations of teachers to librarians and students to librarians during library sessions were part of data gathered that determined the stakeholders' perception of the literacy program. Interview with the parents revealed that most of them are not aware of the information literacy program of the school. Perceptions of school stakeholders are necessary to determine the effectiveness or ineffectiveness of a program. Apparently, the effective strategies used by the librarians discussed in this study such as book talks, read-aloud activities, and classroom interactions are among the creative ways the KEMC librarians have utilized to encourage clientele to participate in the programs and services in place. The worth of library instruction program in school curriculum was stressed by Cayabyab (1976) when she explained that students' information skills should be developed in order to adapt to their learning environment. These skills are honed through library instruction programs that are being carried out by the librarians. In this way, program goals are achieved and the value of library instruction is felt by the school stakeholders. Similar reason is believed in by the AGS librarians for initiating and conducting MIP in the AGS. The collaborative effort of teaching MIP to AGS students shows that librarians are instructional and learning partners.

In 2004, Ballesteros (2004) conducted a graduate study, which aimed to determine the effects of bibliographic instruction to the critical thinking of students. The study used the ASSURE model to come up with bibliographic instruction modules administered to college students enrolled in Divine World College of Laoag. The same model was used by the researcher in this study. The same steps were adapted for the module development. The study emphasized the importance of bibliographic instruction given by teacher-librarians in order to improve students' ability to search, access and retrieve information. However, this study found out that there was no significant difference in the critical thinking of students exposed to bibliographic instruction from those who were not given such.

When Martin (2010) conducted a study on "Outcome Evaluation of the Library Media Program on Information Literacy Skills," two important factors were revealed: (1) the effects of the instructional services provided through school-based library media programs on acquisition of information literacy skills and (2) the effects of the instructional services provided through school-based library media programs on academic achievement. The study used TRAILS, an online multiple-choice tool used to measure students' acquisition of 
information literacy skills developed by Kent State University Department of Libraries and Media Services. The study revealed that most students were proficient in almost all information literacy skills. According to the study, there is a significant relationship between the students' academic achievement in reading and their acquired information literacy skills. Having read this study, the researcher made a multiple-choice test similar to TRAILS. The researcher believes that this type of test is appropriate for elementary students as they are required to pick the best answer out of the given choices.

The BIG6 (Eisenberg \& Berkowitz, 1988) approach involves six systematic steps in measuring the information literacy skills of students - task definition, information seeking, location and access, use of information, synthesis, and evaluation. It has been used by K12 schools in teaching information literacy skills. In using this approach, students are trained to learn the authentic problem solving skills and they are exposed to diverse learning opportunities to capture different ways of learning. The BIG6 skills were the bases of the researcher when the pre-test and the post-test items were constructed. Educators have to direct learners to solve their daily problems not only in school but also in their day-to-day routines at home utilizing appropriate sources of information.

\section{Methodology}

The study used a one-group pretest-posttest experimental design of research. It involved one group which was pre-tested, exposed to an intervention, and then post-tested. Students were treated as experimental group. A pre-test was given to students in September 2015 to determine the level of their information literacy skills. After having determined their information literacy skills, Media Instruction Program modules were administered. The posttest was administered after the implementation of MIP modules. The difference in the percentages of the pre-test and the post-test scores indicated the gains in the level of information literacy skills of the students.

\section{Research Instruments}

The pre-test and the post-test were objective multiple choice type of test. The test items were based on the skills and topics discussed in the MIP sessions. These varied from task definition, information seeking, location and access, use of information, synthesis and evaluation skills. The researcher made use of the BIG6 model as a reference in making the test items to ensure that essential skills are covered. Furthermore, the online Tool for Realtime Assessment of Information Literacy Skills (TRAILS), a project developed by Kent State University Libraries, was explored by the researcher in constructing the test items. There were five items for each module, both for the pre-test and the post-test. Each test item aimed to answer a specific objective with corresponding skills to be measured. 


\section{The Respondents}

The respondents of this study were the selected Grade Five students enrolled in the Ateneo de Manila Grade School for SY 2015-2016. They belong to heterogeneous group whose ages range from nine to ten years old. The profile of the students revealed that most of them belong to average and above average learners who are highly capable of doing activities that require higher order thinking skills. The researcher included 251 Grade Five students to be the respondents of the study as they come from the sections assigned to the researcher to teach MIP. The number of respondents was decreased to 238 because students with incomplete pre-test and post-test were eliminated.

Purposive sampling was done to address the need that only one teacher would implement the modules and administer the tests. Grade Five students were chosen to be the subject of the study because it is in this level that information search and information use are beginning to introduce. All respondents were treated as experimental group.

\section{Results}

\section{The Pre-test Information Literacy Skills of Grade Five Students}

The pre-test scores of the Grade Five students are clustered between three points to 17 points. No student scored perfect and no student scored 0 , as such it can be said that they had information literacy skills. This describes that more than half of the students' pre-test scores are satisfactory as the passing score was set at 10.151 students passed the pretest $(63.3 \%)$.

\section{The Post-test Information Literacy Skills of Grade Five Students}

The students' post-test scores are clustered between nine points to 20 points. 23 students scored perfect and three scored nine, as such it can be said that they had information literacy skills. This reveals that the Grade Five students' post-test scores are very satisfactory. Majority of the students' scores are above the passing score which was set at 10. 235 students passed the post-test (98.7\%).

\section{The Difference in the Pre-test and the Post-test Information Literacy Skills of Grade Five Students}

To determine whether the information literacy instruction was effective, the pre-test and posttest scores were compared. In the pre-test, the highest score was 17 and 23 students perfected the post-test. Majority of the students got higher scores in the post-test than in the pre-test. Only 151 students got a passing mark in the pretest while 235 students got a passing mark in the post test; considering that the passing score was set at 10 . About 
$63.3 \%$ of the population passed the pre-test while $98.7 \%$ of the population passed the posttest. This describes that there was an improvement in the students' post-test scores after going through MIP sessions. There was an observed increase in the post-test as seen in the students' scores.

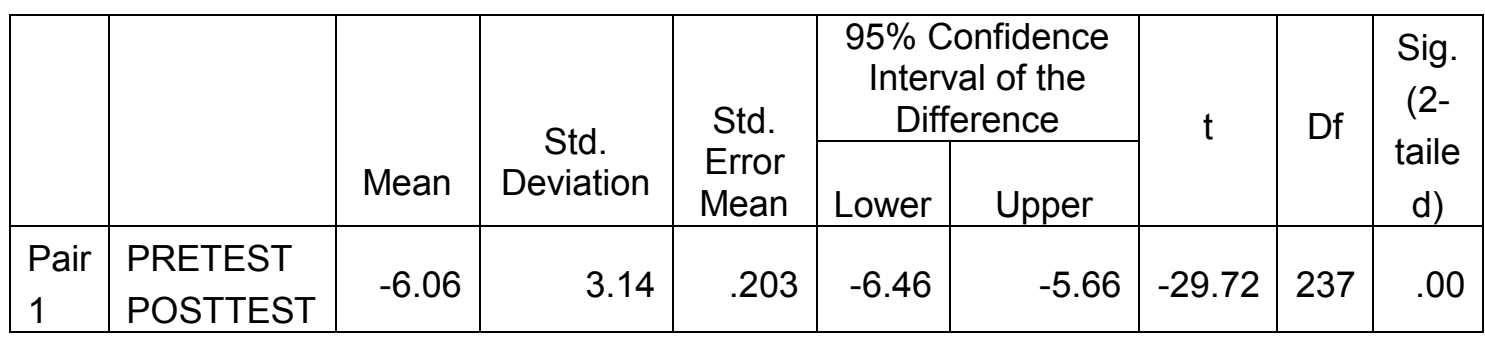

In the pre-test, the mean was 10.28 with a standard deviation of 2.65. Likewise, when the 238 students answered the post-test, the mean was 16.34 and with a standard deviation of 2.71. This means that after the intervention, the mean score of the population improved from 10.28 to 16.34 . The standard deviation proves that fewer scores deviated from the mean in the post test as opposed to the pretest. The result of the T-test showed that there is a significant positive difference between the pre-test and post-test scores of the Grade Five students. It indicates that the Media Instruction Program modules had a very significant positive impact on the test scores of the Ateneo de Manila Grade School Grade Five students. The table shows the difference of the two means $(10.28-16.34=-6.06) ; 16.34$ being the mean score of the post-test and 10.28 being the mean score of the pre-test. Subtracting the mean score of the post-test from the mean score of the pre-test gives a difference of -6.06 . The average distance of the data from the mean is 3.14 . $T$ value is related to the size of the difference between the means of the two samples that are being compared. Since the t-value is -29.72 , that means that the smaller the t-value, the lesser is the difference. Since .00 is less than .05 , so $\mathrm{H}_{0}$ is rejected. Thus, there is a significant positive difference between the pre-test and the post-test scores of the AGS Grade Five students.

\section{$T$ tests Inferential statistics between the pre-test and post-test scores}

The correlation between the pre-test and the post-test is given in the third column, where $r$ $=.314$. The last column gives the $p$ value for the correlation coefficient. $p$ becomes more significant as it approaches 0 . This means that since the population correlation coefficient ( $\rho)$ is equal to 0 that is, $p=.00$, the null hypothesis can be rejected. Thus, there is a significant relationship between the pre-test and the post-test scores.

$T$ tests correlation between the pre-test and post-tests scores 


\section{Conclusions}

Based on the findings, the following conclusions were derived from the study:

1. The Media Instruction Program of the KEMC was a good intervention to teach students become independent users of information. The study determined that the MIP is an integral part of the school's academic program.

2. The study revealed that the MIP had a very significant positive impact on the test scores of the AGS Grade Five students.

3. The study revealed that the Ateneo de Manila Grade School librarians played a key role in training students maximize the use of KEMC resources, programs and services.

\section{Recommendations}

\begin{tabular}{|l|l|c|c|c|}
\hline & & $\mathrm{N}$ & Correlation & Sig. \\
\hline Pair 1 & PRETEST \& POSTTEST & 238 & .314 & .00 \\
\hline
\end{tabular}

Based on the conclusions and findings, the following are the recommendations:

\section{On Module Development}

1. Librarians should have a periodic review of the Media Instruction Program content and lesson plans to ensure that appropriate information literacy skills per grade level are included in the program implementation.

2. Librarians should continuously collaborate with the English teachers and among the librarians to come up with a well-defined Media Instruction Program.

3. Librarians should consider including criterion-referenced assessment in the MIP lesson plans to be able to measure the outcome of the lessons. In this way, the librarians would be able to determine the influences of the lessons on the students' learning environment.

\section{On Professional Development}

Librarians should consistently update themselves professionally through attendance in seminar-workshops to be able to carry out the Media Instructional Program very well.

\section{On Program Implementation}


The Media Instruction Program should be regularly implemented in all grade levels as there are clear indicators of the program's effectiveness. The MIP schedule should be consistently followed so that all skills and topics are taught to students.

\section{For future researcher}

It is recommended that the developed MIP modules be used by other school librarians and other libraries after incorporating possible revisions to improve the lessons. 


\section{APPENDICES}

THE TABLE OF SPECIFICATIONS OF THE PRE-TEST/POST-TEST

\begin{tabular}{|c|c|c|c|}
\hline Lesson & Item & Objectives & Skills \\
\hline \multirow[t]{5}{*}{$\begin{array}{l}\text { 1-Revisiting the } \\
\text { KEMC }\end{array}$} & $\begin{array}{l}\text { 1. Identify the } \\
\text { KEMC service } \\
\text { necessary } \\
\text { when using a } \\
\text { reference } \\
\text { material in the } \\
\text { library }\end{array}$ & $\begin{array}{l}\text { To test the ability of the } \\
\text { student to identify the } \\
\text { KEMC service needed } \\
\text { when using a reference } \\
\text { material in the library }\end{array}$ & $\begin{array}{l}\text { Task definition } \\
\text { Information } \\
\text { seeking }\end{array}$ \\
\hline & $\begin{array}{l}\text { 2. Identify the } \\
\text { KEMC service } \\
\text { necessary } \\
\text { when using } \\
\text { online } \\
\text { information } \\
\text { sources }\end{array}$ & $\begin{array}{l}\text { To test the ability of the } \\
\text { student to identify the } \\
\text { KEMC service that } \\
\text { would help him explore } \\
\text { online information } \\
\text { sources }\end{array}$ & $\begin{array}{l}\text { Task definition } \\
\text { Information } \\
\text { seeking } \\
\text { Location \& } \\
\text { Access }\end{array}$ \\
\hline & $\begin{array}{l}\text { 3. Identify the } \\
\text { KEMC service } \\
\text { necessary } \\
\text { when finding } \\
\text { books in the } \\
\text { library }\end{array}$ & $\begin{array}{l}\text { To test the ability of the } \\
\text { student to locate library } \\
\text { books; } \\
\text { To test the ability of the } \\
\text { student to inform the } \\
\text { librarian about his } \\
\text { needs }\end{array}$ & $\begin{array}{l}\text { Task definition } \\
\text { Information } \\
\text { seeking } \\
\text { Location \& } \\
\text { Access }\end{array}$ \\
\hline & $\begin{array}{l}\text { 4. Know the new } \\
\text { books available } \\
\text { in the library }\end{array}$ & $\begin{array}{l}\text { To test the ability of the } \\
\text { student to be updated } \\
\text { on the new books } \\
\text { available in the library }\end{array}$ & $\begin{array}{l}\text { Task definition } \\
\text { Location \& } \\
\text { Access }\end{array}$ \\
\hline & $\begin{array}{l}\text { 5. Identify the } \\
\text { KEMC service } \\
\text { necessary } \\
\text { when displaying } \\
\text { one's collection } \\
\text { in school }\end{array}$ & $\begin{array}{l}\text { To test the ability of the } \\
\text { student to find ways } \\
\text { how one's collection can } \\
\text { be displayed in school }\end{array}$ & $\begin{array}{l}\text { Task definition } \\
\text { Information } \\
\text { seeking }\end{array}$ \\
\hline \multirow[t]{2}{*}{$\begin{array}{l}2 \text { - Dewey Decimal } \\
\text { Classification }\end{array}$} & $\begin{array}{l}\text { 6. Be familiar with } \\
\text { DDC system }\end{array}$ & $\begin{array}{l}\text { To test the ability of the } \\
\text { student to know DDC } \\
\text { system }\end{array}$ & Task definition \\
\hline & $\begin{array}{l}\text { 7. Identify Arabic } \\
\text { numbers } \\
\text { assigned to } \\
\text { science books }\end{array}$ & $\begin{array}{l}\text { To test the ability of the } \\
\text { student to locate } \\
\text { science books in the } \\
\text { library }\end{array}$ & $\begin{array}{l}\text { Location\& } \\
\text { Access }\end{array}$ \\
\hline
\end{tabular}




\begin{tabular}{|c|c|c|c|}
\hline & 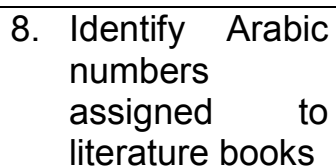 & $\begin{array}{l}\text { To test the ability of the } \\
\text { student to locate } \\
\text { literature books in the } \\
\text { library }\end{array}$ & $\begin{array}{l}\text { Location\& } \\
\text { Access }\end{array}$ \\
\hline & $\begin{array}{l}\text { 9. Distinguish how } \\
\text { Filipiniana non- } \\
\text { fiction books } \\
\text { are arranged in } \\
\text { the library }\end{array}$ & $\begin{array}{l}\text { To test the ability of the } \\
\text { student to describe the } \\
\text { arrangement non-fiction } \\
\text { Fllipiniana nona } \\
\text { books in the library }\end{array}$ & $\begin{array}{l}\text { Location } \\
\text { Access }\end{array}$ \\
\hline & $\begin{array}{l}\text { 10. Use } \text { OPAC } \\
\text { when finding } \\
\text { library books }\end{array}$ & $\begin{array}{l}\text { To test the ability of the } \\
\text { student to use OPAC } \\
\text { appropriately }\end{array}$ & $\begin{array}{l}\text { Information } \\
\text { seeking } \\
\text { Location } \\
\text { Access }\end{array}$ \\
\hline \multirow[t]{5}{*}{$\begin{array}{l}3 \quad-\quad \text { Reference } \\
\text { Information Sources }\end{array}$} & $\begin{array}{l}\text { 11. Determine the } \\
\text { reference } \\
\text { information } \\
\text { source to be } \\
\text { used in finding } \\
\text { the criteria for } \\
\text { choosing } \\
\text { recipients of the } \\
\text { National Artist } \\
\text { Award }\end{array}$ & $\begin{array}{l}\text { To test the ability to } \\
\text { determine the } \\
\text { appropriate reference } \\
\text { information source to be } \\
\text { used in finding the } \\
\text { criteria for choosing } \\
\text { recipients of the } \\
\text { National Artist Award }\end{array}$ & $\begin{array}{l}\text { Task definition } \\
\text { Information } \\
\text { seeking } \\
\text { Location \& } \\
\text { Access }\end{array}$ \\
\hline & $\begin{array}{l}\text { 12. Find synonyms } \\
\text { of given words } \\
\text { using correct } \\
\text { reference } \\
\text { information } \\
\text { source }\end{array}$ & $\begin{array}{l}\text { To test the ability to } \\
\text { locate synonyms of } \\
\text { words using correct } \\
\text { reference information } \\
\text { source }\end{array}$ & $\begin{array}{l}\text { Task Definition } \\
\text { Information } \\
\text { seeking } \\
\text { Location \& } \\
\text { Access }\end{array}$ \\
\hline & $\begin{array}{l}\text { 13. Differentiate a } \\
\text { college from a } \\
\text { university }\end{array}$ & $\begin{array}{l}\text { To test the ability to } \\
\text { differentiater given } \\
\text { subjects/topics using } \\
\text { appropriate information } \\
\text { source }\end{array}$ & $\begin{array}{l}\text { Task Definition } \\
\text { Information } \\
\text { seeking } \\
\text { Location \& } \\
\text { Access }\end{array}$ \\
\hline & $\begin{array}{l}\text { 14. Find the route } \\
\text { going } \\
\text { Intramuros }\end{array}$ & $\begin{array}{l}\text { To test the ability to find } \\
\text { the route going to } \\
\text { Intramuros using } \\
\text { appropriate reference } \\
\text { information source }\end{array}$ & $\begin{array}{l}\text { Task Definition } \\
\text { Information } \\
\text { seeking } \\
\text { Location \& } \\
\text { Access }\end{array}$ \\
\hline & $\begin{array}{l}\text { 15. Locate } \\
\text { information on } \\
\text { Waste } \\
\text { Management }\end{array}$ & $\begin{array}{l}\text { To test the ability to } \\
\text { locate information on } \\
\text { Waste Management } \\
\text { using appropriate } \\
\text { reference information } \\
\text { source }\end{array}$ & $\begin{array}{l}\text { Task Definition } \\
\text { Information } \\
\text { seeking } \\
\text { Location \& } \\
\text { Access }\end{array}$ \\
\hline \multirow[t]{2}{*}{ 4-Graphic Novels } & $\begin{array}{l}\text { 16. Differentiate } \\
\text { graphic novels } \\
\text { from other } \\
\text { types of books } \\
\text { in the library }\end{array}$ & $\begin{array}{l}\text { To test the ability of the } \\
\text { student to describe } \\
\text { graphic novels }\end{array}$ & $\begin{array}{l}\text { Task definition } \\
\text { Information } \\
\text { seeking }\end{array}$ \\
\hline & 17. Identify the & To test the ability of the & Location \\
\hline
\end{tabular}




\begin{tabular}{|c|c|c|c|}
\hline & $\begin{array}{l}\text { graphic novels } \\
\text { section in the } \\
\text { library }\end{array}$ & $\begin{array}{l}\text { student to identify the } \\
\text { graphic novels section } \\
\text { in the library }\end{array}$ & Access \\
\hline & $\begin{array}{l}\text { 18. Describe } \\
\text { graphic novels }\end{array}$ & $\begin{array}{l}\text { To test the ability of the } \\
\text { students to identify the } \\
\text { characteristics of } \\
\text { graphic novels }\end{array}$ & $\begin{array}{l}\text { Information } \\
\text { seeking }\end{array}$ \\
\hline & $\begin{array}{l}\text { 19. Compare } \\
\text { comics and } \\
\text { graphic novels }\end{array}$ & $\begin{array}{l}\text { To test the ability of the } \\
\text { student to compare } \\
\text { comics and graphic } \\
\text { novels }\end{array}$ & $\begin{array}{l}\text { Use } \\
\text { information }\end{array}$ \\
\hline & $\begin{array}{l}\text { 20. Locate graphic } \\
\text { novels in the } \\
\text { library }\end{array}$ & $\begin{array}{l}\text { To test the ability of the } \\
\text { student to locate } \\
\text { graphic novels in the } \\
\text { library }\end{array}$ & $\begin{array}{l}\text { Location } \quad \& \\
\text { Access } \\
\text { Use } \\
\text { Information }\end{array}$ \\
\hline \multirow[t]{5}{*}{$5-\underset{\text { viewing }}{\mathrm{TV}}$} & $\begin{array}{l}\text { 21. Identify } \\
\text { science } \\
\text { program }\end{array}$ & $\begin{array}{l}\text { To test the ability of the } \\
\text { student to identify the } \\
\text { topics of TV programs }\end{array}$ & $\begin{array}{ll}\text { Use } & \text { of } \\
\text { information }\end{array}$ \\
\hline & $\begin{array}{l}\text { 22. Identify a TV } \\
\text { program on } \\
\text { current events }\end{array}$ & $\begin{array}{l}\text { To test the ability of the } \\
\text { student to differentiate } \\
\text { TV programs }\end{array}$ & $\begin{array}{l}\text { Use } \\
\text { information }\end{array}$ \\
\hline & $\begin{array}{lr}\text { 23. Know } & \text { the } \\
\text { contents } & \text { of } \\
\text { sports } & \text { TV } \\
\text { program } & \end{array}$ & $\begin{array}{l}\text { To test the ability of the } \\
\text { student to compare } \\
\text { sports and cartoon TV } \\
\text { programs }\end{array}$ & $\begin{array}{ll}\text { Use } & \text { of } \\
\text { information }\end{array}$ \\
\hline & $\begin{array}{l}\text { 24. Describe } \\
\text { responsible TV } \\
\text { viewer }\end{array}$ & $\begin{array}{l}\text { To test the ability of the } \\
\text { student to describe a } \\
\text { responsible TV viewer }\end{array}$ & Synthesis \\
\hline & $\begin{array}{l}\text { 25. Determine the } \\
\text { appropriate TV } \\
\text { rating suitable } \\
\text { for his aqe }\end{array}$ & $\begin{array}{l}\text { To test the ability of the } \\
\text { student to determine } \\
\text { which TV rating is } \\
\text { suitable for his age }\end{array}$ & Evaluation \\
\hline
\end{tabular}




\begin{tabular}{|l|l|}
\hline \multicolumn{1}{|c|}{ Skills } & \multicolumn{1}{c|}{ Indicators } \\
\hline 1. Task Definition & $\begin{array}{l}1.1 . \quad \text { The student is able to define the } \\
\text { problem. } \\
1.2 . \quad \text { The student is able to identify the } \\
\text { information needed to complete the } \\
\text { task. }\end{array}$ \\
\hline
\end{tabular}




\begin{tabular}{|c|c|}
\hline 2. Information Seeking Strategies & $\begin{array}{l}\text { 2.1. The student is able to determine all } \\
\text { possible sources. } \\
\text { 2.2. The student is able to select the } \\
\text { best source. }\end{array}$ \\
\hline 3. Location \& Access & $\begin{array}{l}\text { 3.1. The student is able to locate } \\
\text { sources. } \\
\text { 3.2. The student is able to find } \\
\text { information within sources. }\end{array}$ \\
\hline 4. Use of Information & $\begin{array}{l}\text { 4.1. The student is able to engage the } \\
\text { information in a source. } \\
\text { 4.2. The student is able to extract } \\
\text { relevant information }\end{array}$ \\
\hline 5. Synthesis & $\begin{array}{l}\text { 5.1. The student is able to organize } \\
\text { information from multiple sources. } \\
\text { 5.2. The student is able to present the } \\
\text { result. }\end{array}$ \\
\hline 6. Evaluation & $\begin{array}{l}\text { 6.1. The student is able to judge the } \\
\text { result (effectiveness). } \\
\text { 6.2. The student is able to judge the } \\
\text { process (efficiency). }\end{array}$ \\
\hline
\end{tabular}


Module 1 - Revisiting the Katigbak Educational Media Center (KEMC)

\begin{tabular}{|c|c|}
\hline Context & $\begin{array}{l}\text { This lesson gives a comprehensive } \\
\text { understanding of the importance of KEMC in } \\
\text { the Ateneo de Manila Grade School (AGS). }\end{array}$ \\
\hline Learning Outcomes & $\begin{array}{l}\text { The students will be able to: } \\
\text { 1. Distinguish the different resources, } \\
\text { programs and services of the KEMC } \\
\text { 2. Recognize the KEMC as an important } \\
\text { part of the school } \\
\text { 3. Use KEMC resources, programs and } \\
\text { services appropriately }\end{array}$ \\
\hline Learning Experiences & $\begin{array}{l}\text { 1. Have the students recall KEMC } \\
\text { guidelines. } \\
\text { 2. Discuss pertinent details on the use of } \\
\text { KEMC as an important service unit of } \\
\text { the AGS. } \\
\text { 3. Have a discussion on the following: } \\
\text { - KEMC programs } \\
\text { - KEMC services } \\
\text { - KEMC guidelines for students } \\
\text { 4. Group the students into five. Have } \\
\text { the students identify KEMC programs } \\
\text { and services. Have them discuss } \\
\text { among themselves the reasons why } \\
\text { these programs and services are } \\
\text { present. There should be at least one } \\
\text { program/service that will be shared in } \\
\text { class. } \\
\text { 5. Have them make a new program } \\
\text { which they think is necessary to } \\
\text { improve the KEMC as a service unit } \\
\text { of the AGS. } \\
\text { 6. Give the students time to reflect on } \\
\text { this question:As a Grade } 5 \text { student, } \\
\text { how will I be able to maximize the use } \\
\text { of KEMC programs and services? }\end{array}$ \\
\hline Learning Skills & $\begin{array}{l}\text { 1. Distinguishing KEMC resources and } \\
\text { services } \\
\text { 2. Recalling KEMC guidelines } \\
\text { 3. Using KEMC resources appropriately }\end{array}$ \\
\hline Time frame & 40 minutes \\
\hline
\end{tabular}




\section{Lecture on Revisiting the KatigbakEducational Media Center (KEMC)}

Welcome the students to the Katigbak Educational Media Center (KEMC). Show photos of KEMC activities participated in by Grade 5 students. Review the mission and vision of the KEMC in the AGS. Have the students define the role of the KEMC. Lead the students to the discussion of the KEMC programs and services.

Elicit from the students KEMC programs and services they are familiar with. Based on the given programs and services, enjoin the students to discuss the importance of each program and/or service. Allow the students to distinguish which programs and services they have used. Give them time to share in class their experiences in using these programs and services.

KEMC programs and services for students:

\section{Selection and acquisition service}

The librarians continually select and acquire print and non-print materials that suit the needs, interest and special abilities of the students. Students are encouraged to take active part in the selection process. Book selection with students is done to select books for evaluation. An acquisition form is availabe for book requests.

\section{Organization service}

All purchased print and non-print materials are organized using the Dewey Decimal Classification System (DDC). The materials are automated using the LISA6 program (Library Information Systems Administrator) This organization facilitates the retrieval of materials. Students may check the Online Publis Access Catalog (OPAC) regarding the book's availability.

\section{Circulation service}

The KEMC lends out various types of materials to students. There is a written circulation guideline for the students.

\section{Reference service}

The librarians and staff of the KEMC attend to reference queries of library clientele. A reference logbook is available to document queries.

\section{Bibliographic Service}


There are listings of materials and periodical articles to publicize the new acquisitions.

These are accessible through a semestral publications BITS (Books Information Technology and Services) Listings are also seen at the Ateneo de Manila University website.

\section{Photocopying service}

A photocopying machine is available for office use. Teachers and students are allowed to photocopy materials needed for classroom instruction and learning. A corresponding amount is charged for photocopied materials requested by the students. There is a guideline for photocopying services.

\section{Publicity and Exhibits}

The EMC has regular displays and exhibits in different library and AV areas. The displays and exhibits include library books and AV materials, teachers' and students' collection and works.

\section{E-reference service}

The e-reference area of the library provides opportunities for students to access online sources of information. List of recommended Uniform Resource Locator (URL) is provided at the e-reference area.

After having discussed the different programs and services offered by the KEMC, have the students create a new program or service which they think would help motivate KEMC patrons to maximize its resources. 
Module 2 - Dewey Decimal Classification

\begin{tabular}{|l|l|}
\hline Context & $\begin{array}{l}\text { This lesson is prepared for Grade } 5 \text { students } \\
\text { to be acquainted with how the library } \\
\text { resources are organized in the library. }\end{array}$ \\
\hline Learning Outcomes & $\begin{array}{r}\text { The students will be able to: } \\
\text { 1. Identify the } 10 \text { main } \\
\text { classes/divisions of the Dewey } \\
\text { Decimal Classification System. } \\
\text { 2. Differentiate fiction books from } \\
\text { non-fiction book books } \\
\text { Understand the value of } \\
\text { organizing library resources using } \\
\text { the Dewey Decimal Classification }\end{array}$ \\
\hline
\end{tabular}




\begin{tabular}{|c|c|}
\hline & $\begin{array}{l}\text { System } \\
\text { 4. Locate non-fiction books using } \\
\text { their assigned call numbers in the } \\
\text { DDC scheme } \\
\text { 5. Write a letter to Mr. Dewey about } \\
\text { their insights on DDC }\end{array}$ \\
\hline Learning Experiences & $\begin{array}{l}\text { 1. Lecture on Dewey Decimal } \\
\text { Classification System. } \\
\text { 2. Elicit from the students the two types } \\
\text { of books that can be found in the } \\
\text { library (Fiction and Non-Fiction). } \\
\text { Show samples of fiction and non- } \\
\text { fiction books. Have the students } \\
\text { differentiate fiction books from non- } \\
\text { fiction books. } \\
\text { 3. Present the story about the Dewey } \\
\text { Decimal Classification and discuss the } \\
10 \text { main classes/divisions. } \\
\text { 4. Introduce to the students "My Dewey } \\
\text { Body Buddy." Use this when } \\
\text { discussing the } 10 \text { main } \\
\text { classes/divisions. } \\
\text { 5. Have the students answer a Learning } \\
\text { Activity Sheet (LAS) }\end{array}$ \\
\hline Learning Skills & $\begin{array}{l}\text { 1. Identifying the } 10 \text { classes/divisions in } \\
\text { the DDC system } \\
\text { 2. Distinguishing fiction from non-fiction } \\
\text { books } \\
\text { 3. Locating non-fiction books using DDC } \\
\text { system }\end{array}$ \\
\hline Time frame & 40 minutes \\
\hline
\end{tabular}

\section{Lecture on Dewey Decimal Classification System}

Have them observe how the books are arranged in the library. Elicit answers from students.

Lead them to the discussion of the two types of books found in the library (Fiction and Nonfiction). Have them differentiate fiction books from non-fiction books. Discuss them the area where non-fiction books are located.

Focus on how non-fiction books are arranged in the library (by call number). Present the story about the Dewey Decimal Classification system. Introduce Melvil Dewey, a librarian 
and a reformer who invented the Dewey Decimal Classification system. He was also the founder of the American Library Association. Dewey believed that "A library's function is to give the public in the quickest and cheapest way information, inspiration, and recreation. If a better way than the book can be found, we should use it."

Distribute the DDC Chart.

Discuss the 10 main classes of DDC and show examples of books for each class. Have the students participate in identifying examples of books found in each class of DDC. Discuss the 10 main classes using "The Dewey Body Buddy." Introduce BIBO, a KEMC mascot whose name means Boys Into Books. Encourage students to be inspired by BIBO's love for reading.

After having discussed the way books are organized in the library, have the students write a letter to Mr.Melvil Dewey about their insights on the Dewey Decimal Classification. 


\section{The Dewey Body Buddy}
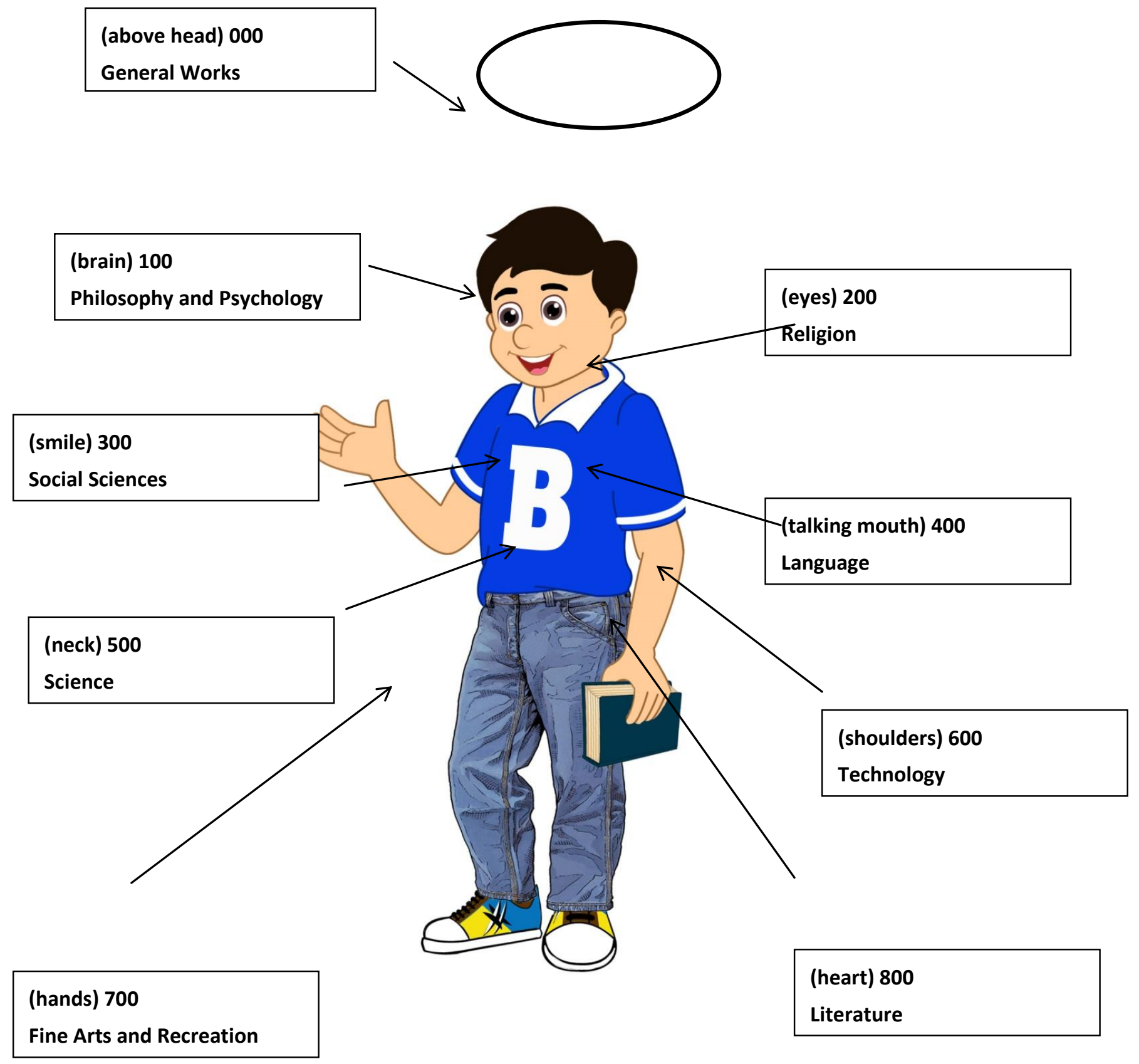


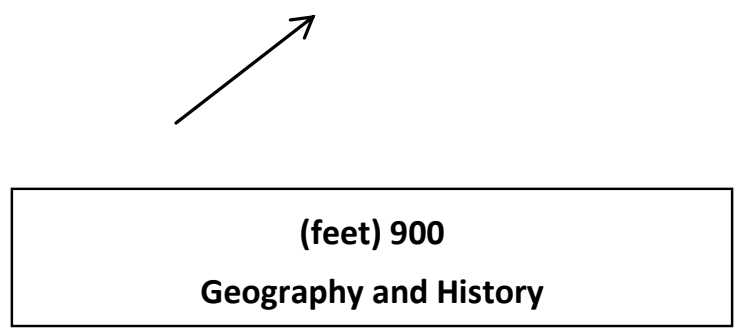

Module 3 - Reference Information Sources

\begin{tabular}{|c|c|}
\hline Context & $\begin{array}{l}\text { This lesson is prepared for Grade } 5 \text { students. } \\
\text { AGS students are trained to use the different } \\
\text { reference information sources at the KEMC. }\end{array}$ \\
\hline Learning Outcomes & $\begin{array}{l}\text { The students will be able to: } \\
\text { 1. Differentiate the reference } \\
\text { information sources at the KEMC } \\
\text { 2. Access information using the } \\
\text { reference information sources } \\
\text { 3. Appreciate the importance of } \\
\text { reference information sources to } \\
\text { improve literacy } \\
\text { 4. Use reference information sources } \\
\text { appropriately }\end{array}$ \\
\hline Learning Experiences & $\begin{array}{l}\text { Lecture on reference information sources. } \\
\text { Students will be paired and will be asked to } \\
\text { provide the needed information by using } \\
\text { appropriate reference materials. They will be } \\
\text { asked to indicate the type and title of } \\
\text { reference information source used. } \\
\text { a. Guide words of the word } \\
\text { 'photosynthesis' } \\
\text { b. Languages spoken in China and its } \\
\text { population } \\
\text { c. Height of the tallest mountain in } \\
\text { d. Furope } \\
\end{array}$ \\
\hline
\end{tabular}




\begin{tabular}{|c|c|}
\hline & $\begin{array}{l}\text { e. Who is the current president of } \\
\text { Greece? } \\
\text { f. How many syllables are in the word } \\
\text { ENUNCIATE? } \\
\text { After having introduced the specialized } \\
\text { reference information sources, students will } \\
\text { be asked to answer the following: } \\
\text { 1. Your CLE teacher gave you an } \\
\text { assignment on the Sacraments of the } \\
\text { Church. Which of the following } \\
\text { specialized reference information } \\
\text { sources can help you find the } \\
\text { information you need? } \\
\text { a. Catholic Almanac } \\
\text { b. Encyclopedia of Saints } \\
\text { c. Who's Who in the Bible } \\
\text { d. The Book of Inventions } \\
\text { This book contains fascinating facts } \\
\text { and unforgettable achievements by } \\
\text { people, animals, minerals, vegetables, } \\
\text { and mechanicals focused on the } \\
\text { sensational efforts of record-holders } \\
\text { who went beyond the average in } \\
\text { setting and breaking a world } \\
\text { record. What specialized reference } \\
\text { source is this? } \\
\text { a. Motorsports Encyclopedia } \\
\text { b. Time Almanac for Kids } \\
\text { c. Guinness World Records } \\
\text { d. None of the above } \\
\text { Zeus, Athena, Vulcan, } \\
\text { Hephaestus...are some of known } \\
\text { Mythology Gods and Goddesses. To } \\
\text { learn more about these mythology } \\
\text { characters, what specialized } \\
\text { reference source would you use? } \\
\text { a. The Dictionary of Mythology } \\
\text { b. World Almanac Book of Records } \\
\text { c. Historical Atlas of Dynasties and } \\
\text { d. Encyclopedia of Science }\end{array}$ \\
\hline Learning Skills & $\begin{array}{l}\text { Differentiating diverse reference information } \\
\text { sources at the KEMC } \\
\text { Using reference information sources } \\
\text { appropriately }\end{array}$ \\
\hline Time frame & 80 minutes \\
\hline
\end{tabular}




\section{Lecture on Reference Information Sources}

Elicit from the students what they KNOW and what they WANT to know about reference information sources. Lead the students to the discussion of reference information sources.

Introduce the different reference information sources at the KEMC. Reference information sources are materials used to find information about people, places, things, and events. Highlight the use and features of the given reference information sources:

a. Encyclopedia - a reference information source that gives a summary of either all branches of knowledge or specific topics. It consists of articles or entries arranged alphabetically. It provides more detailed information than those in dictionaries. 
b. Almanac - a reference information source published annually which gives information on different topics

c. Dictionary - a reference information source that gives meanings of words arranged in an alphabetical order. Dictionaries also give information such as etymology, syllabication, and pronunciation

d. Thesaurus - a reference information source book of words and their synonyms

e. Atlas - is a collection of maps

Show examples for each type of reference information source.

Highlight the new reference information sources available in the library like Time for Kids Almanac 2016, National Geographic Kids Almanac 2016, World Almanac 2016, Guinness World Records 2016. Introduce online reference information sources that can be used at the e-reference section such as www.infoplease.com, www.merriam-webster.com, www.goodreads.com, www.thesaurus.com, www.worldalmanac.com, guinnessworldrecord app, waze app, etc. Invite students to share other online reference information sources they have used.

Characteristics of Reference Materials

a. Non-circulating -reference books cannot be checked out of the library

b. Quick facts - reference books are not read straight through, like novels; you usually simply 'refer' to them when you need quick, basic information

c. Overview - reference books provide a quick introduction to your topic, a quick overview; these overviews are especially helpful when your begin researching a topic you don't know much about

d. Bibliographies, Cross References \& See-also References - because discussions on topics in reference books are not in-depth, entries include suggestions to review related articles within the book itself (cross and see-also references) and citations to other related, in-depth sources (bibliographies)

e. Specific arrangement - reference books are organized in very specific ways, depending on the type of book. For example, chronologies are arranged by date, dictionaries are arranged in alphabetical order by word, and encyclopedias are arranged in alphabetical order by subject.

(Source: Grace Hauenstein Library Acquinas College, 2013) 
Kinds of reference materials:

a. General Reference Information Sources - contain articles on many subjects of general interests. Show examples of general information sources.

b. Specialized Reference Information Sources - contain articles that deal with only one

(1) subject or topic. Present examples of specialized reference information sources.

1. Art atlas

2. Catholic Almanac

3. Historical Atlas of Dynasties and Royal Houses

4. Encyclopedias of Holidays and Celebrations

Have the students describe the contents and features of the given examples of general and specialized reference information sources. Invite them to think of situations when they would need to use these reference information sources. Let them share their experiences regarding the use of reference information sources.

After having discussed the different reference information sources, have the students compose a poem about a reference information source. 
Module 4 - Graphic Novels

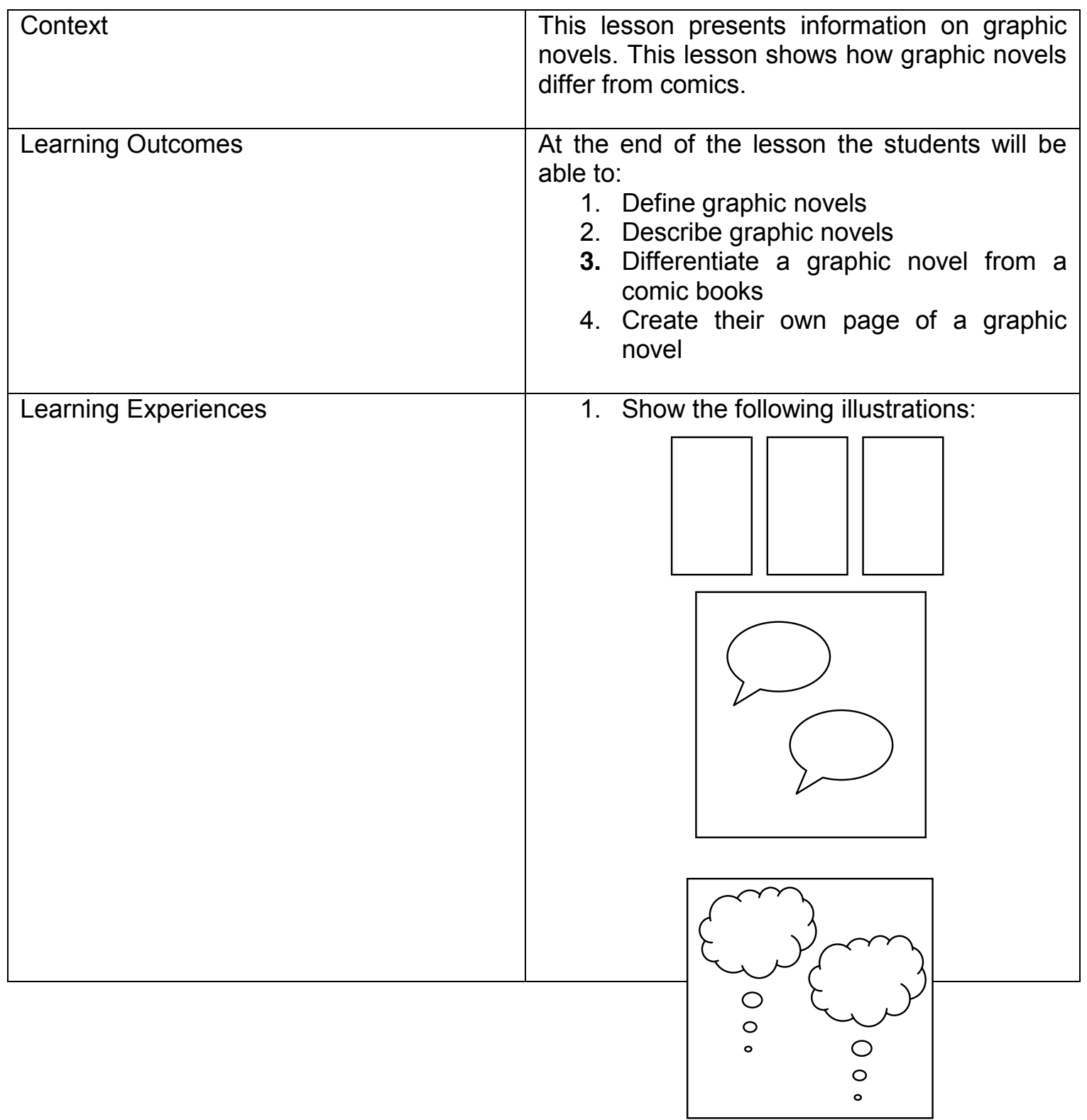




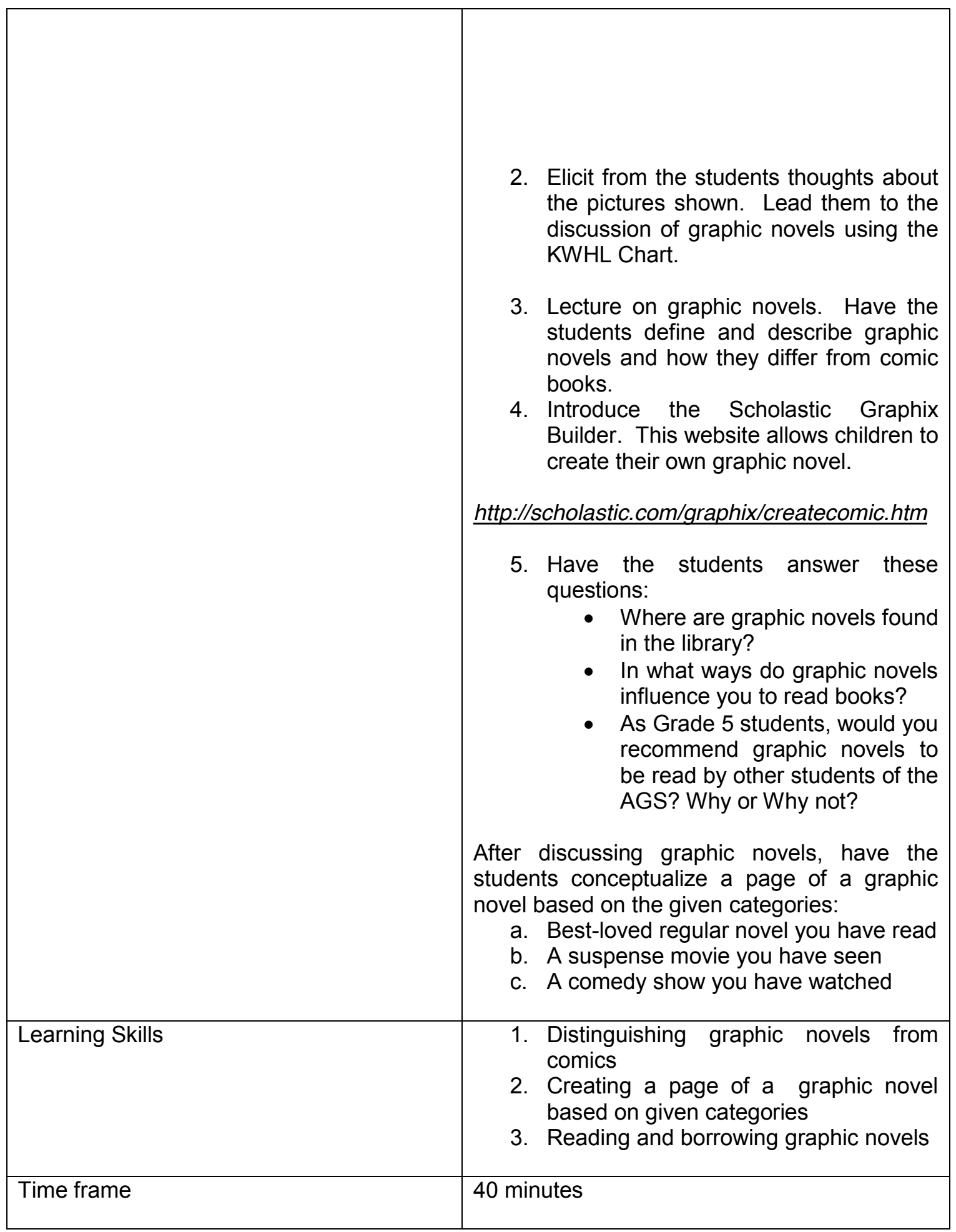




\section{Lecture on Graphic Novels}

Show samples of graphic novels in the library. Have the students describe the books presented. Lead the students to the discussion of graphic novels. Graphic novels are novels presented in sequential art. Anything in comics format that's long enough to have a spine is called a graphic novel. They are located at the Children's Section of the library. When describing graphic novels, it is best to distinguish the important terminologies in a graphic novel. These are:

Panel - The action in comics most commonly happens in sequential boxes. These boxes are called panels.

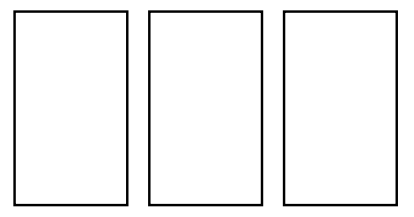

Word Balloon - Dialogue in comics occurs in the form of word balloons - text-filled circles or ovals with long tails that lead to the mouths of the characters speaking 


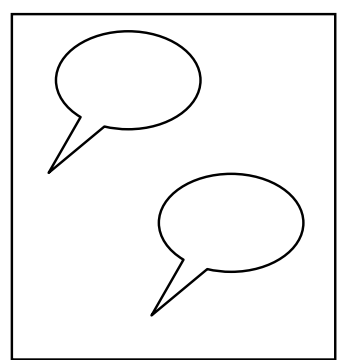

Thought Balloon - Thoughts in comics occur in the form of thought balloons - typically cloud-shaped circles containing text or images that indicate the characters' thoughts. These balloons will be positioned above the characters' heads, with a trail of small clouds leading from the balloons to their heads.

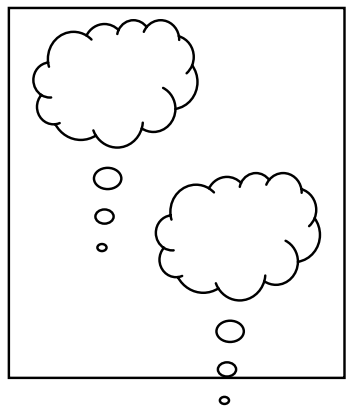

Comics vs Graphic novels

Comics are serials and are assigned an International Standard Serial Number (ISSN) while graphic novels are considered books and are registered with an International Standard Book Number (ISBN)

Comics and graphic novels differ on how they are published. Comics have a paper cover and are released in serial comic magazines. Meanwhile, graphic novels are single published materials often in book form and have softbound or hardbound editions.

The story in comics is released in parts while graphic novels are released as a whole and stand-alone material. 
The storyline in comics can begin at any point of the story while the graphic novel follows the typical pattern of novels that involves a beginning, middle, and an ending.

Comics often have a light comedy feel. In contrast, graphic novels offer mature themes aimed at a young or adult audience.

Source: http://www.differencebetween.net/ 


\section{Module 5 - TV Ratings}

\begin{tabular}{|c|c|}
\hline Context & $\begin{array}{l}\text { This lesson presents the different ratings of } \\
\text { television programs. }\end{array}$ \\
\hline Learning Outcomes & $\begin{array}{l}\text { At the end of the lesson the students will be } \\
\text { able to: } \\
\text { 1. Distinguish different forms of media } \\
\text { 2. Identify the different TV ratings } \\
\text { 3. Differentiate ratings given to TV } \\
\text { programs }\end{array}$ \\
\hline Learning Experiences & $\begin{array}{l}\text { 1. Lecture on TV viewing. } \\
\text { 2. Have the students identify the } \\
\text { different forms of media as pictures } \\
\text { are shown. } \\
\text { 3. Have the students focus on television. } \\
\text { Have the students give examples of } \\
\text { TV programs they watch. } \\
\text { 4. Group the students into four. Have } \\
\text { them give top five (5) TV programs } \\
\text { they usually watch. }\end{array}$ \\
\hline Learning Skills & $\begin{array}{l}\text { 1. Recognizing ratings of TV programs } \\
\text { 2. Differentiating ratings of television } \\
\text { programs }\end{array}$ \\
\hline Time Frame & 40 minutes \\
\hline
\end{tabular}




\section{Lecture on TV viewing}

Introduce the different forms of media by showing pictures of books, newspapers, magazines, music, film, television, mobile phones, computers, laptop, and ipod.

Lead the students to the discussion of the different forms of media. Guide the students in clustering the pictures shown to be able to identify the three major forms of media:

1. Print media - books, newspapers, magazines

2. Electronic media - ebooks, ejournals, music, television

3. New Age media - mobile phones, gadgets, laptop

Lead the class to focus on television. Have the students identify TV programs they watch. Have the students share what information they get from watching TV programs. Elicit from the students how the information they get from TV viewing help them as Grade 5 students.

Have the students share their insights on the following effects of TV viewing:

- TV affects social and emotional behavior

- TV affects school achievement

- TV affects creativity and language skills

Discuss the ratings given to TV programs

1. General Patronage (G) - suitable for all ages. Material for television does not contain anything unsuitable for children.

2. Parental Guidance (PG) - parental guidance suggested. Material for television may contain some adult material but may be permissible for children to watch but only under the guidance and supervision of a parent or adult. 
3. Strong Parental Guidance (SPG) - strong and more vigilant parental guidance is suggested. Programs classified under SPG may contain more serious topic and theme, which may not be advisable for children to watch except under the very vigilant guidance and presence of a parent or adult.

Have the students answer the following questions:

1. How will you show that you are a responsible TV viewer?

2. How can television programs help you in your studies?

3. What are the benefits of knowing the ratings given to TV programs

\section{PRE-TEST/POST-TEST}

Name:

Class Number:

Section:

Age:

Read the sentences. Encircle the letter of your answer.

1. Which of the following services of the KEMC would help you have a copy of a page from a Science encyclopedia which is not allowed to be taken out of the library?
a. circulation service
b. e-reference service
c. organization service 

d. photocopying service

2. You are asked to know more about the website www.nationalgeographic.com. What service of the library would help you explore this website?
a. circulation service
b. e-reference service
c. photocopying service
d. selection service

3. Your English teacher assigned you to read the novel The Tale of Despereaux by Kate DiCamillo. After checking this book in the KEMC OPAC, you found out that the two (2) copies are currently out. What do you think is the best thing to do?
a. ask your classmate to tell you the story of the novel
b. tell your English teacher that you won't be able to read the book
c. borrow a book from your classmate and photocopy the whole book
d. fill out a book request acquisition form and request for another copy of the book

4. You want to know the new books available in the library. What would you do to be updated on this?
a. check the internet to see the new releases for 2015
b. visit the library and check the list of new books posted
c. ask your classmates what new books they have read recently
d. ask the librarian about the record of books you borrowed from the library

5. You treasure your collection of bookmarks given by your family, teachers and friends. You want your schoolmates to see these in school. What would you do?
a. tell your classmates to buy bookmarks
b. describe your bookmarks to your classmates
c. count your bookmarks and distribute them among your classmates
d. coordinate with the librarian and have your bookmarks collection displayed in the library


6. The library uses Dewey Decimal Classification scheme (DDC) to arrange books and other library materials on the shelves so they may be easily retrieved. How many categories are there in the DDC?
a. 4 topics
b. 5 sections
c. 8 divisions
d. 10 classes

7. Which of the following is the set of numbers designated for science books?
a. 200-299
b. 300-399
C. $500-599$
d. $800-899$

8. In the DDC system what subject or topic is assigned to $800-899$ books?
a. literature
b. religion
c. sports
d. story

9. What is the arrangement of Filipiniana non-fiction books on the shelves?
a. alphabetical order
b. call number
c. chronological order
d. random numbers

10. What will you do if you want to find a book in the library but you do not know its call number?
a. use the OPAC
b. go to the shelves in the library and check the title
c. refer to a dictionary
d. use the table of contents of a book 
11. What reference information source would you use to find the criteria for choosing recipients of the National Artist Award?
a. Almanac
b. Dictionary
c. Encyclopedia
d. Thesaurus

12. You are asked by your teacher to look for the synonyms of the words ambiguous, credible and pertinent. What is the best reference information source that you would use?
a. Almanac
b. Atlas
c. Encyclopedia
d. Thesaurus

13. What reference information source would you use to differentiate a college from a university?
a. Almanac
b. Atlas
c. Dictionary
d. Encyclopedia

14. What reference information source would you use to know the route going to Intramuros?
a. Almanac
b. Atlas
C. Encyclopedia
d. Dictionary

15. You are assigned to report on Waste Management. What reference information source would you use to be able to get information about your topic?
a. Almanac
b. Atlas
c. Encyclopedia 


\section{d. Dictionary}

16. What number is used to register graphic novels?
a. International Standard Book Number (ISBN)
b. International Standard Brochure Number (ISBN)
c. International Standard Handout Number (ISHN)
d. International Standard Serial Number (ISSN)

17. What section in the library are graphic novels located?
a. Carpeted Area
b. Children's Section
c. General Collection Section
d. Periodical Section

18. Which of the following statements is TRUE about graphic novels?
a. Graphic novels are published weekly, monthly, or quarterly.
b. Graphic novels come in a non-book format
c. Graphic novels follow the typical pattern of novels that involves a beginning, middle, and an ending.
d. Graphic novels are usually sold in comic stores, newsstands, or the stands near the counters of bookstores, supermarkets, and convenient stores.

19. Which of the sentences below shows a good comparison between comics and graphic novels?
a. Comics and graphic novels are released in parts.
b. Comics are for library use only while graphic novels can be borrowed for two weeks.
c. Comics are located at the reference area while graphic novels are located at the children's section.
d. The story in comics is released in parts while graphic novels are released as a whole and stand-alone material.

20. What are the steps in finding graphic novels in the library? 
a. List down titles of graphic novels and put your paper in the suggestion box.

b. Go to the General Collection Section of the library and check the books in the 500 section.

c. Check the OPAC, type in the title or author, get the call number of the book and go to the shelf.

d. Go to the circulation counter and check the returned graphic novels in the box at the circulation counter.

21. Which of the following TV programs would help you get information on dinosaurs?
a. Asian Food Channel
b. Cartoon network
c. National Geographic
d. Sports Illustrated

22. What TV program would you recommend to a Grade 5 student if he wants to be updated on current events?
a. CNN
b. MYX
c. Animal planet
d. Sports and Action

23. Which of the following TV programs will NOT give you information on sports?
a. Balls
b. Basketball TV
c. Toonami
d. Star sports

24. Which of the sentences below is NOT a characteristic of a responsible TV viewer?

a. A responsible TV viewer thinks critically while watching TV.

b. A responsible TV viewer imitates all the things he sees on TV.

c. A responsible TV viewer makes his assignments prior to watching TV

d. A responsible TV viewer is aware of the number of hours he spends in watching TV. 
25. Which of the following TV ratings is suitable for you even without the presence of your parent or guardian?
a. $\mathrm{G}$
b. GP
c. $P G$
d. SPG

\section{ANSWER KEY}

1. $D$

2. $B$

3. D

4. B

5. D

6. D

7. C

8. A

9. $\mathrm{B}$

10. A

11. A

12. D

13. $\mathrm{C}$

14. $\mathrm{B}$

15. C

16. A

17. B

18. C

19. D

20. C 
21. C

22. A

23. C

24. B

25. A

\section{REFERENCES}

\section{Books}

American Association of School Librarians [and] Association for Educational Communications and Technology. (1998). Information power: Building partnerships for learning. Chicago: American Library Association.

Bisho, K. (2011). Connecting libraries with classrooms: The curricular roles of the media specialist (2nd ed). Santa Barbara, CA: Linworth.

Blanchett, H., Powis, C. \& Webb, J. (2012). A guide to teaching information literacy : 101 
practical tips. London: Facet Publishing.

Brophy, P. (2007). The library in the twenty-first century (2nd ed.). London: Facet Publishing.

Church, A. (2003). Leverage your library program to help raise test scores: a guide for library media specialists, principals, teachers, and parents. Worthington, Ohio: Linsworth.

Cox, C.N., et al. (ed.) (2008). Information literacy instruction handbook. Chicago: Association of College and Research Libraries.

Eisenberg, M.B. \& Berkowitz, R.E. (1988). Curriculum initiative: an agenda and strategy. Norwood, NJ: Ablex Publishing.

Eisenberg, M.B. \& Berkowitz, R.E. (2011). The Big6 workshop handbook: implementation and impact ( $4^{\text {th }}$ edition). Santa Barbara, California: ABC-CLIO, LLC.

Farmer, L. \& Henri, J. (2008). Information literacy assessment in K-12 settings.Lanham, Maryland : Scarecrow Press.

Gayne, R., Briggs, L., \& Wager, W. (1992). Principles of instructional design (4 $4^{\text {th }}$ ed.) Australia: Wadsworth.

Gredler, M.E. (1996). Program evaluation. Englewood Cliffs, NJ: Merrill.

Grix, J. \& Watkins, G. (2010). Information skills: finding and using the right resources. New York: Palgrave Macmillan.

Johnson, B. \& Christensen, L. (2012). Educational research: quantitative, qualitative, and mixed approaches. $\left(4^{\text {th }}\right.$ ed). Los Angeles: Sage Publications.

Joint Committee on Standards for Educational Evaluation (1994). The program evaluation standards: how to assess evaluations of educational programs $\left(2^{\text {nd }}\right.$ ed.) ThousandOaks, CA: Sage Publications.

Kraat, S. B. (ed.) (2005). Relationships between teaching faculty and teaching librarians. New York: Haworth Information Press. 
Mendrinos, R. (1994). Building information literacy using high technology: A guide for schools and libraries. Englewood, CO: Libraries Unlimited.

Murray, R. (2011). How to write a thesis ( $3^{\text {rd }}$ ed.) England: McGraw Hill.

Reiser, R, \& Dick, W. (1996), Instructional planning: a guide for teachers.Boston: Allyn \& Bacon.

Reisman, J. \& Clegg, J. (2000). Outcomes for Success! Seattle, WA: The Evaluation Forum.

Rosenfeld, E. \& Loertscher, D. (ed.) (2007). Toward $21^{\text {st }}$ century school library media program. Lanham, Maryland : The Scarecrow Press.

Rossi, P., Lipsey M. \& Freeman, H. (2004). Evaluation: a systematic approach. $\left(7^{\text {th }}\right.$ ed). Thousand Oaks, CA: Sage Publications.

Royse, D., Thyer, B. \& Deborah K. (2010). Program evaluation: an introduction. (5 $5^{\text {th }}$ ed). Australia: Wadsworth.

Salvia, J. and Hughes, C. (1990). Curriculum-based assessment: testing what is taught. New York: Macmillan.

Squires, D. A. (2009). Curriculum alignment: research-based strategies for increasing student achievement. Thousand Oaks, CA: Corwin Press.

Taylor, J. (2006). Information literacy and the school library media center. USA: Libraries Unlimited.

Thomas, N. (2011). Information literacy and information skills instruction : applying research to practice in the $21^{\text {st }}$ century school library ( $3^{\text {rd }}$ ed.). Santa Barbara, California : Libraries Unlimited.

Wiles, J. \& Joseph Bondi (1998). Curriculum development: a guide to practice $\left(5^{\text {th }}\right.$ ed). Upper Saddle River, New Jersey: Merrill.

Yarbough, D...[et al] (2010). The program evaluation standards: a guide for evaluators and 
evaluation users. $\left(3^{\text {rd }}\right.$ ed). Thousand Oaks, CA: Sage Publications.

Journal article - online

Johnson, D.W. (1986, Fall). Evaluation of Library Literacy Projects. Library Trends,

Retrieved September 23,2012,from

https://www.ideals.illinois.edu/bitstream/handle/2142/7483/librarytrendsv35i2l opt.pdf

?sequence $=1$

Martin, E.C. (2010, October). Outcome Evaluation of Library Media Program on Information Literacy Skills. MCPS Evaluation Brief, Retrieved December 5, 2012, from http://montgomeryschoolsmd.org/departments/sharedaccountability/reports/2010/Brie f\%20Info\%20Literacy 09 10.pdf

Portwood, T.B. (1936, May). The Library as the Heart of the School. Junior-Senior High School Clearing House,10(9). Retrieved July 2, 2013, from http://www.jstor.org/stable/30181129?seq $=3$

Sakr, R. (2009, January). Description and Evaluation of the Information Literacy Program in a Private School in Lebanon: A Case Study. School Libraries Worldwide 15(1). Retrieved August 3, 2013, from http://ca.vlex.com/vid/description-evaluation-literacy-lebanon-65774627

\section{Manual}

AGS KEMC (2008). Katigbak Educational Media Center Manual of Information.

Ateneo de Manila Grade School Quezon City.

Ateneo de Manila Grade School (2012) Ateneo de Manila Grade School Planner. Ateneo de Manila Grade School Quezon City.

\section{Unpublished}

Albania, P.S. (2010). A Study on the borrowing patterns of the middle school students (Grades 4-7) of the Asterio J. Katigbak Educational Media Center (KEMC) of the Ateneo de Manila Grade School through analysis of book circulation. Unpublished M.L.I.S. special problem, University of the Philippines Diliman, School of library and Information Studies. 
Ballesteros, K.L.M. (2004). Bibliographic instruction and critical thinking.Unpublished M.L.I.S. thesis, University of the Philippines Diliman, Institute of Library and Information Science.

Buenrostro, J.C. (1992). An evaluation of graduate library instruction programs in institutions of high learning. Unpublished PhD in Education dissertation, University of the Philippines Diliman, College of Education.

Cayabyab, M.L.A. (1976). The Integration of library instruction in the MiddleSchool curriculum at the International School. Unpublished M.L.I.S. thesis, University of the Philippines Diliman, Institute of Library and Information Science.

Esteves, V.G. (2013). The Curricular needs of the Multi-dimensional Ateneo Gifted Intervention Scheme (MAGIS) Math Program of the Ateneo de Manila University Grade School Department. Unpublished MaEd. Basic Education Teaching. action research, Ateneo de Manila University, Faculty of Education Department.

Ganipes, B.T. (2010). Assessing information literacy of the selected high school students of Saint Louis High School - Philex with emphasis on library instruction. Unpublished B.L.I.S. thesis, University of the Philippines Diliman, School of Library and Information Studies.

Sy, J.Y. (2005). The development of a library instruction program for the St. Stephen's High School Library with emphasis on improving specific library-related skills. Unpublished M.L.I.S. thesis, University of the Philippines Diliman, Institute of Library and Information Science.

\section{Website}

ACRL. (2003). Characteristics of Programs of Information Literacy that Illustrate Best Practices: A Guideline. Retrieved November 26, 2012, from http://www.ala.org/ala/acrl/acrlstandards/characteristics.htm

ACRL. (2003). Guidelines for Instruction Programs in Academic Libraries Approved. Retrieved November 26, 2012, from http://www.ala.org/ala/acrl/acrlstandards/guidelinesinstruction.htm 


\section{Biographical note}

Maria Victoria E. Dela Cruz is a teacher-librarian at the Ateneo de Manila Grade School. She is an accreditor of Basic Education of the Philippine Accrediting Association of Schools, Colleges and Universities (PAASCU). She edited the Senior High School textbook entitled "\#MediaTrends: Importance of New Media Technology to Modern Filipinos written by Ligaya Hidalgo and Mattheus Mopera, published and printed by Don Bosco Press, Inc. She is a graduate of Bachelor of Secondary Education major in Library Science from the University of Santo Tomas. She obtained her Master of Library and Information Science from the School of Library and Information Studies, University of the Philippines Diliman. She is a former Coordinator of the Ateneo de Manila Grade School Katigbak Educational Media Center (KEMC). 